\title{
PROSTATE INNERVATION AND LOCAL ANESTHESIA IN PROSTATE PROCEDURES
}

\author{
Alexandre Oliveira Rodrigues, Marcos Tobias Machado and Eric Roger \\ Wroclawski
}

RHCFAP/3108

\begin{abstract}
RODRIGUES AO et al. - Prostate innervation and local anesthesia in prostate procedures. Rev. Hosp. Clín. Fac. Med. S. Paulo 57(6):287-292, 2002.
\end{abstract}

The nerve supply of the human prostate is very abundant, and knowledge of the anatomy contributes to successful administration of local anesthesia. However, the exact anatomy of extrinsic neuronal cell bodies of the autonomic and sensory innervation of the prostate is not clear, except in other animals. Branches of pelvic ganglia composed of pelvic (parasympathetic) and hypogastric (sympathetic) nerves innervate the prostate. The autonomic nervous system plays an important role in the growth, maturation, and secretory function of this gland. Prostate procedures under local anesthesia, such as transurethral prostatic resections or transrectal ultrasound-guided prostatic biopsy, are safe, simple, and effective. Local anesthesia can be feasible for many special conditions including uncomplicated prostate surgery and may be particularly useful for the high-risk group of patients for whom inhalation or spinal anesthesia is inadvisable.

DESCRIPTORS: Prostate. Innervation. Prostate Surgery. Transrectal ultrasound-guided prostatic biopsy. Local anesthesia.

\section{INTRODUCTION}

The prostate gland is a complex musculoglandular organ composed of secretory elements and tubuloalveolar glands surrounded by smooth muscle 1 . The glandular elements are concerned with the secretion of a majority of the seminal fluids, and the muscular elements contribute to continence and ejaculation ${ }^{2}$.

The autonomic nerve supply of the pelvic genital organs is regulated via adrenergic, cholinergic, and nonadrenergic-noncholinergic peptidergic nerve fibers. Branches of pelvic ganglia composed of pelvic (parasympathetic) and hypogastric (sympathetic) nerves innervate the prostate ${ }^{3}$. Prostatic innervation governs the control of micturition and ejaculation ${ }^{4}$.
The prostate has a rich nerve supply that includes many nerves, which are difficult to individualize, as well as intramural ganglia. Fibers with diameters greater than $95 \mathrm{~mm}$ are particularly dense in the capsule and caudal prostate, and numerous nerves with diameters greater than $30 \mathrm{~mm}$ are found in the urethra ${ }^{2}$.

This innervation also has implications concerning prostate cancer. Fifty percent of the intracapsular invasions of prostate cancer follow the nerve pathways. When a cancer lesion spreads towards the supramontanal urethra, its progression could be along these nerves to the bladder neck. When

From the Department of Urology, Faculty of Medicine of the $\mathrm{ABC}$. cancer develops in the prostate apex, it may spread to the striated sphincter ${ }^{5}$.

\section{PROSTATE INNERVATION}

Sympathetic fibers originate in the lateral column of gray matter of the last 3 thoracic and first 2 lumbar segments of the spinal cord, traverse the lumbar sympathetic paravertebral chain, and reach the pelvic plexus through the superior hypogastric plexus and pelvic continuation of the sympathetic trunks. The superior hypogastric plexus is formed by sympathetic fibers from the celiac plexus and the first 4 lumbar splanchnic nerves that divides into 2 hypogastric nerves ${ }^{1,6-12}$. The prostate has a sympathetic nerve supply that is 5 or 6 times 
greater than the other chromaffin organs $^{13}$.

The existence of parasympathetic supply to the prostate has been controversial ${ }^{4}$. Parasympathetic fibers arise from the intermediolateral cell column of second, third, and fourth sacral spinal nerves. They emerge as pelvic splanchnic nerves to join the hypogastric nerve and branches from the sacral sympathetic ganglia to form the pelvic (inferior hypogastric) plexus ${ }^{2,12}$.

The pelvic plexus is 4 to $5 \mathrm{~mm}$ in length, and its midpoint is at the tips of seminal vesicles ${ }^{14}$. It runs on either side of the rectum and is perforated by numerous vessels going to and from the rectum, bladder, seminal vesicles, and prostate. Division of these vessels proximally formate the lateral pedicles of the bladder and prostate ${ }^{15,16}$. The pelvic plexus, in its caudal portion, gives rise to the innervation of the prostate and to the cavernous nerves ${ }^{15}$. After passing the tips of seminal vesicles, these nerves lie in the lateral endopelvic fascia near its juncture with Denonvilliers' fascia ${ }^{11}$. They run at the posterolateral border of the prostate on the surface of the rectum and are lateral to the prostatic capsular vessels ${ }^{4,17}$. This structure is called the neurovascular bundle. During prostatic surgery, these nerves are most vulnerable at the apex, essentially at the 5- and 7o'clock positions ${ }^{18,19}$. Some nerve fibers from these bundles will terminate in the prostate after perforating the prostate capsule ${ }^{2}$. Other fibers coming from the anterior branches of the pelvic plexus pass around the lateral prostatic surface to join the anterior surface of the bladder neck ${ }^{2}$.

The abundance of alpha adrenergic and muscarinic receptors and nerve fibers suggests that the autonomic nervous system may play a significant role in the growth, maturation, and secretory function of the prostate ${ }^{20}$. The betaadrenergic pathway is partially involved in regulating prostate protein synthesis, messenger RNA expression, and secretion, and for maintaining normal histologic architecture. Norepinephrine has a direct mitogenic effect on prostate stromal cells in vitro ${ }^{21}$. After preganglionic sympathectomy in rat, the ventral prostatic lobe weight decreased $22.7 \%$ by the changes in cell size and cell number. The DNA content also decreased $22.1 \%$, and protein content decreased by $23.9 \%$. After preganglionic parasympathectomy, the weight of the denervated side decreased $8.3 \%$, while the intact side increased significantly by $24.8 \%$. DNA and protein content similarly increased $(29.9 \%$ and $45.1 \%$, respectively) on the intact side and had no decrease on the denervated side. Combined preganglionic parasympathectomy and sympathectomy equalled the sum of the effects of denervation done separately. Therefore, sympathectomy led to atrophy in the lesioned side, while parasympathectomy caused hyperplasia in the intact side ${ }^{20}$. Surgically induced spinal cord injury in rats has resulted in an acute increase in prostate weight. However, by 6 months, prostate weight was not different from those of nonsurgically treated rats ${ }^{22}$.

The nonadrenergic-noncholinergic innervation of the prostate is associated with the following neural peptides: vasoactive intestinal polypeptides, enkephalins, neuropeptide Y, nitric oxide, tyrosine hydroxylase, calcitonin gene-related peptide, and somatostatin; however, their roles have not yet been determined $^{23-28}$. In the human prostate, seminal vesicles, and vas deferens, the rich supply with tyrosine hydroxylase and neuropeptide Y-positive nerve fibers may play a role in the transport of fluids and functional activity of these organs $\mathrm{s}^{27}$. Vasoactive intestinal polypeptides and nitric oxide are neurotransmitter candidates for smooth muscle relaxation, blood flow, and secretion ${ }^{29-31}$.

Concerning the sensory innervation of the prostate, the location of extrinsic neuronal cell bodies that give rise to this innervation is not known, except in some other animals ${ }^{1}$. If studies about bladder innervation are applicable to the prostate, then sensory innervation of the prostate is likely to be functionally significant ${ }^{32-34}$. This has been implied for the symptoms of prostatitis and prostatodynia ${ }^{35,36}$. In cats, most (>90\%) of the primary afferent neurons are located in the sacral dorsal root ganglia. Seventy percent of these sacral primary afferent neurons project axons through the pelvic nerve to reach the prostate, while the remainder $(30 \%)$ project through the pudendal nerve. The remainder of the primary afferent neurons $(10 \%)$ are found in autonomic neurons in the sympathetic chain ganglia, inferior mesenteric ganglia, and ganglia in the pelvic plexus ${ }^{39}$. In rats, most of the afferent neurons are projected in sacral dorsal root ganglia and peripheral ganglia. Most afferent neurons in the sacral dorsal root ganglia are at the level of L6 (40\%) and L5 (20\%) ${ }^{20}$. Twenty-five percent of the innervation of the hemibladder is derived from the contralateral side ${ }^{32}$. A similar bilateral organization of afferent innervation of prostate may exist (Fig.1).

\section{LOCAL ANESTHESIA IN PROSTATE PROCEDURES}

A prostatic block may be achieved by instilling local anesthetic into the pelvic plexuses ${ }^{12}$. Many authors have reported on prostate procedures under local anesthesia, which have proved to be safe, simple, and effective procedures (Table 1).

Nash et al. ${ }^{38}$, in 1996, described transrectal ultrasound guided prostate biopsy using periprostatic anesthesia through a transrectal approach. They injected $1 \%$ lidocaine into 2 locations on each side of the prostate without complications or pain. Soloway and Öbek $^{39}$ have used this procedure, but 


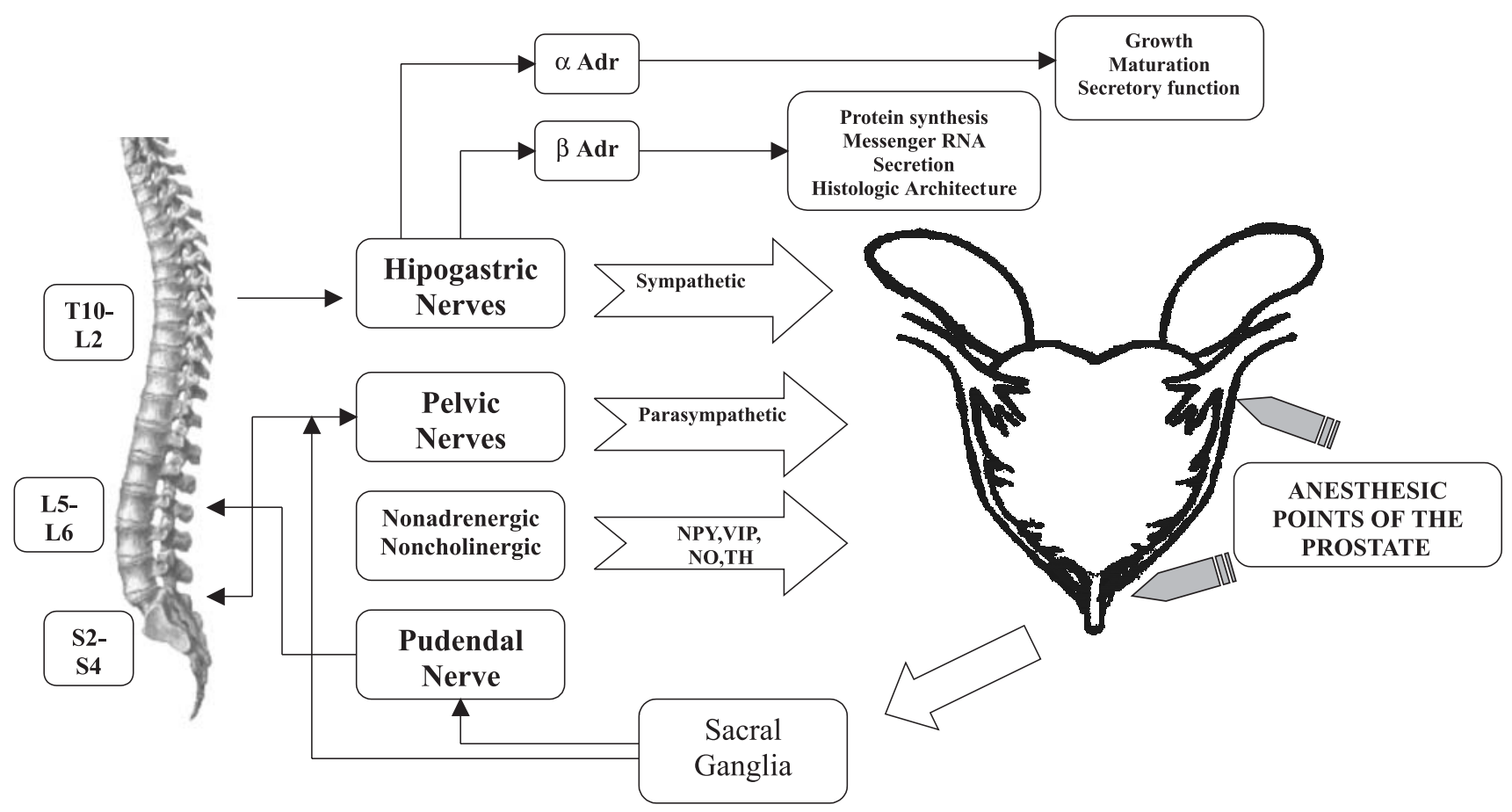

Figure 1 - Prostate Innervation.

Table 1 - Anesthesic alternatives in Prostatic procedures.

Transrectal
Transperineal
Suprapubic
Intraurethral
Sedation

Sedation

with 6 injections, in 50 patients. They reported mild pain in only 1 patient, and there have been no complications. In our experience, additional injections between neurovascular bundles and apex, may be useful in prostates larger than 60 grams.

Campos Freire et al..$^{40}$, in 1997, performed transurethral incision of the prostate on 21 patients for which these other anesthetic procedures were inadvisable, utilizing topical instillation into the urethra and infiltration by injection needle of lidocaine into the vesical neck. It was reported that this procedure was tolerated, with good results. Moffat ${ }^{41}$, in 1977, performed transurethral prostatic resections (TUPR) on 18 patients with benign prostatic hyperplasia under local anesthesia. He used 8 to $10 \mathrm{cc} 1 \%$ lidocaine local infiltration of the prostate through a perineal approach, and topical instillation into the urethra. Nine (50\%) patients needed administration of intravenous narcotic or tranquilizer. Only $2(12 \%)$ had mild discomfort during resection, and there was no major complication. Reddy ${ }^{42}$, in 1990, performed 10 transurethral balloon dilations of the prostate using transperineal periprostatic infiltrations of $15 \mathrm{cc} 1 \%$ lidocaine without any intravenous sedation, with minimal discomfort and no complications. Leach et al. ${ }^{43}$, in 1994 , using a similar type of local anesthesia, performed 46 laser-assisted prostatectomies. The patients tolerated the procedure well, and there were no anesthetic complications. Akalin et al. ${ }^{44}$, in 1998 , performed 54 prostate surgeries, with mild pain in $5(11 \%)$ and significant pain in only 1 patient. Sinha et al. ${ }^{45}$, in 1985 , reported mild pain in $29(48 \%)$ of 60 patients. Twenty-one (35\%) needed sedation. Orandi ${ }^{46}$, in 1984, performed transurethral incision of prostate and re- section of bladder tumors with a resectoscope injection needle and lidocaine infiltration. It was reported that the patients tolerated the process fairly well. Perez ${ }^{47}$ performed TURP with perineal lidocaine injection during intravenous analgesic support and reported excellent results. Tabet and Levine ${ }^{48}$, in 1996, performed periprostatic anesthesia through a suprapubic approach in 40 patients without discomfort or complications.

\section{CONCLUSION}

Prostate procedures, such as TURP or transrectal ultrasound-guided prostatic biopsy, under local anesthesia, are safe, simple, and effective and may be more tolerable than when performed with general anesthesia or spinal block. Additionally, local anethesia can be a feasible anesthetic method for the majority of uncomplicated prostate surgeries and may be particularly useful for the high-risk group of patients when inhalation or spinal anesthesia is inadvisable. 
RODRIGUES AO e col. - Inervação prostática e anestesia local em procedimentos prostáticos. Rev. Hosp. Clín. Fac. Med. S. Paulo 57(6): 287-292, 2002.

A prostáta, uma das glândulas sexuais acessórias masculinas, possui inervação muito rica. A anatomia detalhada dos corpos neuronais extrínsecos responsáveis pela inervação autonômica e sensorial da próstata não está total- mente esclarecida, exceto em animais. A próstata é inervada pelos nervos pélvico (parassimpático) e hipogástrico (simpático), ramos dos gânglios nervosos pélvicos. O sistema nervoso autonômico possui importante papel no crescimento, maturação e na função secretora desta glândula. Alguns procedimentos prostáticos, como resecção transuretral ou biópsia transretal guiada por ultra-sonografia, são simples, eficazes e seguros com o uso de anestesia local. Esta opção pode ser factível frente à várias condições especiais, como cirurgias prostáticas simples, sendo particularmente útil no grupo de pacientes de alto risco cirúrgico, onde a anestesia inalatória ou espinhal não é aconselhável.

DESCRITORES: Próstata. Inervação. Cirurgia prostática. Biópsia prostática guiada por Ultra-som Transretal. Anestesia local.

\section{REFERENCES}

1. KEPPER M \& KEAST J - Immunohistochemical properties and spinal connections of pelvic autonomic neurons that innervate the rat prostate gland. Cell Tissue Res 1995; 281: 533-542.

2. BENOIT G, MERLAUD L, MEDURI G et al. - Anatomy of the prostatic nerves. Surg Radiol Anat 1994; 16: 23-29.

3. VAALASTI A \& HERVONEN - Innervation of the ventral prostate of the rat. Am J Anat 1979; 154: 231-244.

4. DAVIES MRQ - Anatomy of the nerve supply of the rectum, bladder and internal genitalia in anorectal dysgenesis in male. J Ped Surg 1997; 32(4): 536-541.

5. WEIBEL ER - Practical methods for biological morphometry. London, Academic Press, 1979.
6. BENOIT G, DELMAS V, QUILLARD J et al. - Clivage inter prostato rectal: I'intérêt du fascias de Denonvilliers. Presse Med 1983; 12: $2693-94$

7. BENOIT G, GILLOT C \& JARDIN A - Réflexion et proposition sur la nomenclature de la prostate. Surg Radiol Anat 1992; 15: $325-332$.

8. LANGLEY JN \& ANDERSON HK - The innervation within the prostate gland and seminal vesicle. J Physiol 1896; 20: 372379.

9. LATARJET A \& BONNET P - Le plexus hypogastrique chez l'homme. Lyon Chir 1913; 9: 221-228.

10.LEARMONTH JR - A contribution to the neurophysiology of the urinary bladder in man. Brain 1931; 54: 147-153. 
11.LEPOR H, GREGERMAN M, CROSBY R et al. - Precise localization of the autonomic nerves from the pelvic plexus to the corpora cavernosa: a detailed anatomical study of the adult male pelvis. J Urol 1985; 133: 207-212.

12.BROOKS JD: Anatomy of the lower urinary tract and male genitalia. In: WALSH PC, RETIK AB, VAUGHAN EDJ et al. - Campbell's Urology. Philadelphia, Saunders, 1998. p. 89-128.

13.HERVONEN A, VAALASTI A, VAALASTI T et al. - Paraganglia in the urogenital tract of man. Histochemistry 1976; 46: $307-$ 313 .

14.SCHLEGEL PN \& WALSH PC - Neuroanatomical approach to radical cystoprostatectomy with preservation of sexual function. J Urol 1987; 138: 1402-1406.

15.WALSH PC \& DONKER PJ - Impotence following radical prostatectomy: Insight into etiology and prevention. J Urol 1982; 128: 492-497.

16.WALSH PC, LEPOR H \& EGGLESTON JC - Radical prostatectomy with preservation of sexual function: Anatomical and pathological considerations. Prostate 1983; 4: 473-485.

17.PAICK JS, DONATUCCI CF \& LUE TF - Anatomy of cavernous nerves distal to prostate: Microdissection study in adult male cadavers. Urology 1993; 42(2): 145-149.

18.LUE TF, ZEINEH SJ, SCHMIDT RA et al. - Neuroanatomy of penile erection: Its relevance to iatrogenic impotence. J Urol 1992; 131: 273-280

19.BREZA J, ABOSEIF SR \& ORVIS BR - Detailed anatomy of penile neurovascular structures: Surgical significance. J Urol 1992; 148: 1190-1194, 1992.

20.McVARY KT, McKENNA KE \& LEE C - Prostate Innervation. Prostate 1998; 8: 2-13

21.TROMPSON TC, ZHAU H \& CHUNG LWK - Catecolamines are involved in the growth and expression of prostate binding protein by rat ventral prostatic tissues. In: COFFEY DS, BRUCHOVSKY N, GARDNER WA et al. - Current Concepts and Approaches to the Study of Prostate Cancer. New York, Alan R. Liss, 1987. P. 239-248.

22.HUANGH FS, LI MT, LINSENMEYER TA et al. - The effects of spinal cord injury on the status of messenger ribonucleic acid for TRPM 2 and androgen receptor in the prostate of the rat. $\mathbf{J}$ Androl 1997; 18(3): 250-256.

23.BURNETT AL, MAGUIRE MP, CHAMNESS SL et al. Characterization and localization of nitric oxide synthase in the human prostate. Urology 1995; 45: 435-439.

24.VAALASTI A \& HERVONEN A - Autonomic innervation of the human prostate. Invest Urol 1980; 17: 293-297.

25.VAALASTI A, LINNOILA I \& HERVONEN A Immunohistochemical demonstration of VIP, and enkephalin immunoreactive nerve fibers in the human prostate and seminal vesicles. Histochemistry 1980; 66: 89-92.

26.VAALASTI A, TAINO H, PELTO-HUIKKO $\mathrm{M}$ et al. - Light and electron microscope demonstration of VIP and enkephalin immunoreactive nerves in the human male genitourinary tract. Anat Rec 1986; 215: 21-27.
27.TAINIO H - Peptidergic innervation of the human prostate, seminal vesicle and vas deferens. Acta Histochem 1995; 97: 113- 119.

28.CHOW PH, DOCHERY P \& CHEUNG A - Innervation of accessory Sex glands in the adult male golden hamster and quantitative changes of nerve densities with age. Androl 1997; 29: 331342 .

29.STJERNQUIST M, HAKANSON R, LEANDER S et al. Immunohistochemical localization of substance $P$, vasoactive intestinal polypeptide and gastrin-releasing peptide in vas deferens and seminal vesicle, and the effect of these and eight other neuropeptides on resting tension and neurally evokes contractile activity. Regul Peptides 1983; 7: 67- 71.

30.SAID S - Vasoactive intestinal polypeptide (VIP): Current status. Peptides 1984; 5: 143-150.

31.HEDLUND P, EKSTROM P, LARSSON B et al. - Heme oxygenase and NO-synthase in the human prostate - Relation to adrenergic, cholinergic and peptide-containing nerves. J Auton Nerv Syst 1997; 63: 115-126

32.TUTTLE JB, STEERS WD, ALBO $\mathrm{M}$ et al. - Neural input regulates tissue NGF and growth of the adult rat urinary bladder. J Auton Nerv Syst 1994; 49: 147-158.

33.STEERS WD, CIAMBOTTI J, ETZEL B et al. - Alterations in afferent pathways from the urinary bladder of the rat in response to partial urethral obstruction. J Comp Neurol 1991; 310: 401-410.

34.McVARY KT, RAZZAQ A, LEE C et al. - Growth of the rat prostate gland is facilitated by the autonomic nervous system. Biol Reprod 1994; 51: 99-107.

35.DRACH G, MEARES EM, FAIR WR et al. - Classification of benign diseases associated with prostatic pain: prostatitis or prostatodynia. J Urol 1978; 120: 266-27.

36.WEIDNER W - Prostatitis-diagnostic criteria, classification of patients and recommendations for therapeutic trials. Infection 1992; 20: 227-231.

37.DANUSER H, SPRINGER JP, KATOFIASC MA et al. - Extrinsic innervation of the cat prostate gland: A combined tracing and immunohistochemical study. J Urol 1997; 157: 1018-1024.

38.NASH PA, BRUCE JE, INDUDHARA R et al. - Transrectal ultrasound guided prostatic nerve blockade eases systematic needle biopsy of the prostate. J Urol 1996; 155: 607- 609 .

39.SOLOWAY MS \& ÖBEK C - Periprostatic local anesthesia before ultrasound guided prostate biopsy. J Urol 2000; 163: 172-73.

40.CAMPOS FREIRE G, FALCI JR R, AIELLO FILHO D et al. Avaliação da dor em prostatotomia com anestesia tópica uretral - J Bras Urol 1997; 23: 96

41.MOFFAT N - Transurethral prostatic resections under local anesthesia. J Urol 1977; 118: 607-608.

42.REDDY PK - New technique to anesthetize the prostate for transurethral balloon dilation. Urol Clin N Am 1990; 17 (1): $55-56$.

43.LEACH GE, SIRLS L, GANABATHI K et al. - Outpatient visual laser-assisted prostatectomy under local anesthesia. Urol 1994; 43 (2): 149-153. 
44.AKALIN Z, MUNGAN NA, BASAR H et al. - Transurethral resection of the prostate and laser prostatectomy under local anesthesia. Eur Urol 1998; 33:202-205.

45.SINHA B, HAIKEL G, LANGE PH et al. - Transurethral resection of the prostate with local anesthesia in 100 patients. J Urol 1986; 135: 719-721.

46.ORANDI A - Urological endoscopic surgery under local anesthesia: A cost-reducing idea. J Urol 1984; 132: 1146-47.
47.PEREZ JA - Outpatient transurethral resection of prostate. In: KAYE KW (ed) - Outpatient Urologic Survey. Philadelphia, Lea, 1985. P. 120-139.

48.TABET BG \& LEVINE S - Nerve block in prostate surgery. J Urol 1996; 156: 1659-1661.

Received for publication on November 28, 2001. 